\title{
Three-year ground based measurements of aerosol optical depth over the Eastern Mediterranean: the urban environment of Athens
}

\author{
E. Gerasopoulos ${ }^{1}$, V. Amiridis ${ }^{2}$, S. Kazadzis ${ }^{1}$, P. Kokkalis ${ }^{3}$, K. Eleftheratos ${ }^{4,5}$, M. O. Andreae ${ }^{6}$, T. W. Andreae ${ }^{6}$, \\ H. El-Askary ${ }^{7,8}$, and C. S. Zerefos ${ }^{4,5}$ \\ ${ }^{1}$ Institute for Environmental Research and Sustainable Development, National Observatory of Athens, I. Metaxa and Vas. \\ Pavlou, 15236, P. Penteli, Athens, Greece \\ ${ }^{2}$ Insitute for Space Applications and Remote Sensing, National Observatory of Athens, P. Penteli, Athens, Greece \\ ${ }^{3}$ National Technical University of Athens, Laboratory of Lasers and Applications, Athens, Greece \\ ${ }^{4}$ National Kapodistrian University of Athens, Geology Department, Athens, Greece \\ ${ }^{5}$ Biomedical Research Foundation, Academy of Athens, Athens, Greece \\ ${ }^{6}$ Biogeochemistry Department, Max Planck Institute for Chemistry, 55020 Mainz, Germany \\ ${ }^{7}$ School of Earth and Environmental Sciences, Schmid College of Science, Chapman University, Orange, CA, USA \\ ${ }^{8}$ Department of Environmental Sciences, Faculty of Science, Alexandria University, Egypt
}

Received: 18 August 2010 - Published in Atmos. Chem. Phys. Discuss.: 18 November 2010

Revised: 14 February 2011 - Accepted: 21 February 2011 - Published: 10 March 2011

\begin{abstract}
Three years (2006-2008) of ground-based observations of the Aerosol Optical Depth (AOD) in the urban environment of Athens, in the Eastern Mediterranean, are analysed in this work. Measurements were acquired with a Multi-Filter Rotating Shadowband Radiometer at five wavelengths. The daily average AOD at $500 \mathrm{~nm}$ is 0.23 , and the mean Ångström coefficient calculated between 415 and $867 \mathrm{~nm}$ is 1.41 . The annual variability of AOD has a spring maximum dominated by coarse dust particles from the Sahara (AOD 0.34-0.42), while the diurnal pattern is typical for urban sites, with AOD steadily increasing throughout the day. The greatest contribution to the annually averaged AOD, accounting for almost $40 \%$, comes from regional and local sources (namely the Istanbul metropolitan area, the extended areas of biomass burning around the north coast of the Black Sea, power plants spread throughout the Balkans and the industrial area in the Po valley, with average daily AOD in the range of 0.25-0.35). An additional important contribution (23\%) is dust from Africa, whereas the rest of Europe contributes another $22 \%$. The geographical distribution of the above sources in conjunction with the prevailing synoptic situation and contribution of local sources, lead to mixed types of aerosols over Athens, with highly variable contribution of fine and coarse particles to AOD in the range 10\%-90\%. This is the first long-term, ground based data set available for
\end{abstract}

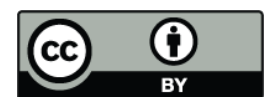

Correspondence to: E. Gerasopoulos (egera@meteo.noa.gr)
Athens, and it has also been used for the validation of satellite derived AOD by MODIS, showing good agreement on an annual basis, but with an overestimation of satellite AODs in the warm period.

\section{Introduction}

Aerosols have long been identified as and included among the major controllers of the Earth's climate (e.g. IPCC, 2001). Despite progress achieved during the last decades in understanding the effects of aerosols on climate, their large spatial-temporal variability and heterogeneity still causes significant uncertainties at global scales (IPCC, 2007). At regional scales, aerosols can affect the climate via radiation forcing and interaction with cloud but also degrade air quality, visibility and public health.

A region receiving much interest with regard to the effects of aerosol is the Mediterranean Basin, especially its eastern part. The particularly high content of atmospheric aerosols in the area, on the order of 2 to 10 times higher than over the least polluted environments at northern latitudes (Lelieveld et al., 2002), has been demonstrated by a number of ground based studies (e.g. Formenti et al., 2001; Andreae et al., 2002; Gerasopoulos et al., 2003; Fotiadi et al., 2006; Kazadzis et al., 2007) and satellite based studies (e.g. Barnaba and Gobbi, 2004; Papadimas et al., 2008; Hatzianastassiou et al., 2009; Karnieli et al., 2009; Koukouli et al.,

Published by Copernicus Publications on behalf of the European Geosciences Union. 
2010). Other studies focus on particular aerosol types such as Saharan dust (e.g. Israelevich et al., 2002; El-Askary et al., 2003; Kubilay et al., 2003; Papayannis et al., 2005; Kalivitis et al., 2007; Prasad et al., 2010;), vegetation (e.g. Liakakou et al., 2009), sea spray (e.g. Kouvarakis et al., 2002), biomass burning (e.g. Balis et al., 2003; Sciare et al., 2008), anthropogenic sulphate (e.g. Sciare et al., 2005) and their effects on radiation (Balis et al., 2004; El-Askary et al., 2008, 2009). High aerosol columnar contents are usually linked to elevated surface levels of particulate matter (e.g. Gerasopoulos et al., 2006, 2007; Koulouri et al., 2008; Querol et al., 2009), that in turn can induce health problems via enhanced inhalation doses (e.g. Griffin et al., 2007; Mitsakou et al., 2008), or to transported particles in elevated layers (e.g. Kalivitis et al., 2007).

Apart from the crucial geographical location of the area as a crossroads of long range transported aerosols from different sources, significant local sources also exist, such as power plants, and urban and industrial agglomerations. The increasing urbanization in the area has led to rapid growth of cities, from populations of 3-5 million (e.g. Athens, Izmir) to the level of "megacities" ( $>10$ million in population) such as Istanbul and Cairo. The role of these "megacities", both as receptors and sources, is indisputably recognised and the evaluation of their role on aerosol load and climatic relevant properties of the Eastern Mediterranean atmosphere is urged (Kanakidou et al., 2010).

Even though significant campaigns focusing on the chemical and meteorological evolution of pollution over Athens have taken place (e.g. the MEDCAPHOT-TRACE campaign, Ziomas, 1998), only few ground based measurements of aerosol columnar loads are available for Athens, and these are mainly confined to shorter period campaigns (e.g. Jacovides et al., 2005; Giavis et al., 2005), or specific aerosol types (e.g. Gerasopoulos et al., 2009; Amiridis et al., 2009). On the other hand, satellite observations have been used to infer aerosol properties over the long term (e.g. Kaskaoutis et al., 2007), but the temporal resolution (one overpass per day) is not adequate to capture the intra-diurnal variation. Moreover, satellite observations need to be validated by ground based measurements.

This study presents three years (2006-2008) of measurements of aerosol optical depth over Athens, Greece, the third most significant, by means of population, urban centre in the Eastern Mediterranean Basin. It is the longest ground based time series available for Athens and it is used for the investigation of the main characteristics of columnar aerosol loads over an urban environment, located in an area of already high regional aerosol background. In Sect. 3.1, aerosol levels and their seasonal variation are presented and compared with similar observations existing for the extended area, while in Sect. 3.2 we provide the diurnal cycle of aerosol optical characteristics. In Sect. 3.3, we utilize cluster analysis in an attempt to identify the major source regions of particles and typical paths for their transport towards the Eastern Mediter- ranean. In Sect. 3.4, we compare our ground based observations with respective satellite products (MODIS) and finally in Sect. 3.5, we apply a graphical method to infer additional aerosol properties such as the contribution of fine and coarse particles to optical depth.

\section{Experimental}

\subsection{Site}

The measurements were conducted on the roof of the Biomedical Research Foundation of the Academy of Athens $\left(37.99^{\circ} \mathrm{N}, 23.78^{\circ} \mathrm{E}\right)$ at approximately $190 \mathrm{~m}$ a.s.l. (Zerefos and Eleftheratos, 2007). The campus is located in a green area at a distance of about $4 \mathrm{~km}$ from the centre of Athens. To the east of the station is Mount Hymettus at a distance of about $1 \mathrm{~km}$, and to the north and northeast of the station the big mountains of the county of Attica, Parnes and Penteli, are located, at distances of about 15 and $20 \mathrm{~km}$, respectively. Finally, to the south, the Saronic Gulf is found at a distance of about $10 \mathrm{~km}$.

\subsection{Instrumentation}

In this study, we have used measurements of the total and diffuse solar irradiance, made using a Multi-Filter Rotating Shadowband Radiometer (MFR-7 Yankee Env. System Inc., Turner Falls, MA), to calculate the direct component of the irradiance. A detailed description of the operation principles of the instrument can be found in Harrison et al. (1994). The MFR provides 1-min average measurements at five wavelengths $(415,500,615,675$ and $867 \mathrm{~nm})$ and from these the Aerosol Optical Depth (AOD) is extracted. The instrument makes valid measurements during daytime and clear sky conditions. Regular calibration checks (autocalibration with estimates of the solar constant, $I_{0}$ ) and instrument maintenance were performed during the period of operation. For a short period, the instrument operated in parallel with the AERONET station "Athens-NOA" CIMEL sunphotometer showing very good agreement (not shown).

\subsection{Methodology}

\subsubsection{AOD retrievals}

The methodology followed for the extraction of the AOD values from direct solar irradiance is thoroughly described in Gerasopoulos et al. (2003). In brief, the Langley linear regression technique (Harrison and Michalsky, 1994) is applied to the direct solar irradiance data, to estimate the solar constant, $I_{0}$, using the criteria for clear-sky days, and the exclusion of highly loaded days, and days with high variation. The Beer-Lambert-Bouguer law $\left(I=I_{0} \cdot e^{-\tau \cdot m}\right)$ is then applied to derive instantaneous measurements of the total optical depth $(\tau)$, where $m$ is the optical mass (airmass). 
Aerosol Optical Depths (AODs) for the five wavelengths are obtained by subtracting the contribution of Rayleigh scattering and ozone absorption from the $\tau$. For the ozone absorption correction, columnar ozone values were taken from the North Hemisphere Ozone Mapping Centre of WMO (http: //lap.physics.auth.gr/ozonemaps2/). For the discrimination between signals from clouds and abrupt changes in aerosol loadings, e.g. dust outbreaks, we utilized maps of cloudiness and dust transport from the Barcelona Super Computing Center-DREAM Atmospheric Dust Forecast System (http://www.bsc.es/projects/earthscience/) and MODIS (http: //modis-atmos.gsfc.nasa.gov/IMAGES/index.html), respectively. From the initial 1-min resolution data, half-hour and daily averages are calculated and used in the analyses that follow.

The most important uncertainties associated with the AOD retrieval from the MFR are the estimation of $I_{0}$, the total ozone correction at ozone absorbing wavelengths and the presence of thin clouds, the latter being hard to quantify. The standard deviation of $I_{0}$ calculated during clearsky, clean days during the period of interest, ranged between $2.5 \%$ and $7 \%$, with higher values for shorter wavelengths. This translates into an uncertainty of $0.02-0.06$ for AOD at $500 \mathrm{~nm}$, for an optical air mass in the range 3 to 1 , respectively. Regarding ozone correction, given an uncertainty of about $3 \%$ to derive vertical columns of ozone from satellites (e.g. Ladstätter-Weissenmayer et al., 2007), then an uncertainty of 0.001-0.0015 for AOD (at maximum ozone absorption wavelengths) is calculated, which is one order lower than the uncertainty from $I_{0}$.

\subsubsection{MODIS retrievals}

MODIS sensors located on the Terra and Aqua satellite platforms offer a broad range of information covering land, oceanic, and atmospheric conditions (Kaufman et al., 1998; Masuoka et al., 1998). The MODIS Terra and Aqua have provided aerosol-related parameters for the entire globe since 2000 and 2002, respectively. In this study we have used data for the period 2006-2008 from MODIS Terra. The MODIS Terra derived AOD over land product (Daily level 2 aerosol products, i.e. MOD04 from Collection 5) at $10 \mathrm{~km}$ spatial resolution was acquired from the NASA Earth Observing System (EOS) Clearinghouse (ECHO). The expected errors in MODIS derived AODs over land are $\pm(0.05+0.15 \times$ AOD) (Remer et al., 2005, 2008) and their description and validation are discussed by Engel-Cox et al. (2004) and Chu et al. (2002), respectively. Further details of the development of the aerosol retrieval algorithm over land are discussed by Remer et al. (2006).

\subsubsection{Cluster analysis}

In this study, a clustering algorithm for atmospheric trajectories, modified from the one recommended by Dorling et al. (1992) was used. This specific algorithm provides the optimum number of clusters, as follows:

First, a set of synthetical seed trajectories is generated. Then each real trajectory is assigned to one seed, by minimizing the 2-D Euclidian distance, considering only the longitude and latitude data of the trajectories. Then an average trajectory of each group is calculated, the so-called centroid. Trajectories are reassigned and their distances from the calculated centroids are checked again. Then centroids are recalculated, and this step is reiterated until all trajectories are correctly assigned. The Root Mean Square Deviation (RMSD) of each trajectory from its centroid is calculated. The algorithm reduces the number of clusters by merging those for which the centroids are closest, and the previous steps are repeated. Each cluster merging leads to a weak increase in the total RMSD. However, when significantly different clusters are merged, then a steep increase in the total RMSD is observed, and this is the criterion of the cluster number optimization. The whole process is repeated with slightly different seed trajectories.

For the application of the cluster analysis, we utilized air mass trajectory information from the HYSPLIT model (Hybrid Single-Particle Lagrangian Integrated Trajectory Model, Draxler and Hess, 1998). In particular, we used 4-day back trajectories arriving at 12:00 UTC over Athens, at an altitude of $1500 \mathrm{~m}$. This altitude is considered characteristic for aerosol transport in the free troposphere for the extended area of study (Mattias et al., 2004; Amiridis et al., 2005).

\section{Results and discussion}

\subsection{AOD levels and seasonal variation}

Monitoring of AOD over Athens took place from January 2006 to December 2008, a time span of 3 years (Fig. 1). Data availability by season, mainly depending on the extent of cloud cover, shows a maximum of $80 \%$ in summer to a minimum of $60 \%$ in winter. Frequency distribution plots for the daily average AOD at $500 \mathrm{~nm}$ and the Ångström coefficient (å) calculated between 415 and $867 \mathrm{~nm}$, are shown in Fig. 2a and b. The daily average AOD at $500 \mathrm{~nm}$ for the whole period is $0.23 \pm 0.17$, with $50 \%$ of the values lying in the range $0.12-0.29$ and maximum frequency class $0.1-0.15$. The daily average å is $1.41 \pm 0.48$, with $50 \%$ of the values lying in the range 1.2-1.8, and with a maximum frequency class of 1.6-1.8. The basic statistics for all wavelengths are given in Table 1.

Long-term ground based monitoring data of AOD for Athens do not exist. However, the newly established "Athens-NOA" AERONET station has been operating 


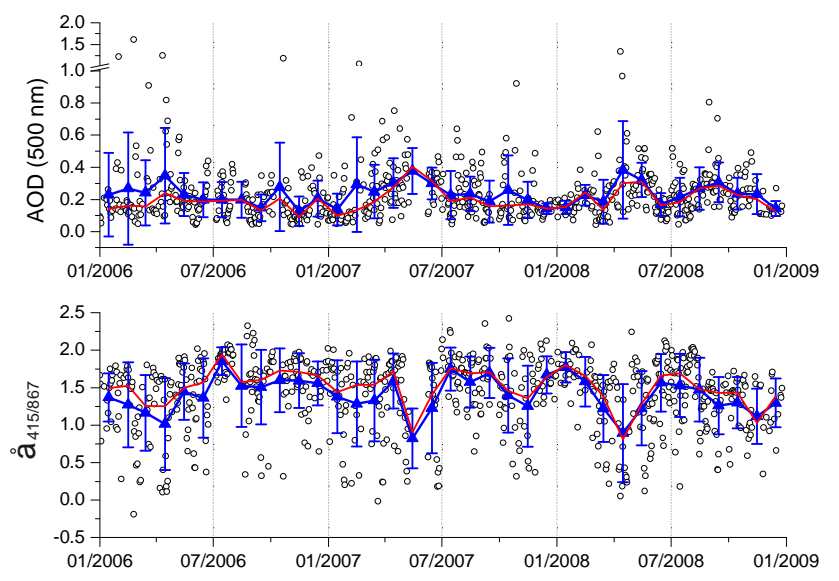

Fig. 1. Time series of daily AOD averages (upper panel) and Ångström coefficient (lower panel) over Athens, for the period 2006-2008. Triangles correspond to the monthly averages of the respective quantities and are accompanied by their standard deviation, while the red thin line represents the monthly medians.

Table 1. Basic statistics on the daily averaged AOD and the Ångström coefficient (å) over Athens, for the period 2006-2008.

\begin{tabular}{lcc}
\hline & Average \pm Stand. Dev. & 1st Quartile-Median-3rd Quartile \\
\hline AOD $_{415}$ & $0.29 \pm 0.18$ & $0.17-0.25-0.37$ \\
OOD $_{500}$ & $0.23 \pm 0.17$ & $0.12-0.19-0.29$ \\
$\mathrm{AOD}_{615}$ & $0.18 \pm 0.16$ & $0.09-0.14-0.22$ \\
$\mathrm{AOD}_{671}$ & $0.16 \pm 0.15$ & $0.07-0.11-0.19$ \\
$\mathrm{AOD}_{867}$ & $0.12 \pm 0.14$ & $0.05-0.08-0.14$ \\
$\stackrel{\circ}{(415 / 867)}$ & $1.4 \pm 0.5$ & $1.2-1.5-1.8$ \\
\hline
\end{tabular}

uninterrupted since February 2009 and constitutes the continuation of our measurements at the same site. Other ground measurement studies report a mean AOD of 0.23 at $500 \mathrm{~nm}$ and an å in the range 1.4-1.6 for the period 1999-2002 at two sites in Northern Greece, Thessaloniki/urban and Ouranoupoli/rural (Gerasopoulos et al., 2003) and a mean AOD of 0.21 at Crete/rural for the period 2003-2004 (Fotiadi et al., 2006). Kazadzis et al. (2007) report AOD at $320 \mathrm{~nm}$ in the range $0.43-0.46$ for the period 1997-2005 at Thessaloniki. In contrast, AOD levels for Athens have been estimated from satellite data, however validation of these data over long periods and for different spatial resolutions, has until now never been performed but is part of this study (Sect. 3.4). In particular, MODIS derived mean AOD at $550 \mathrm{~nm}$ for the period 2000-2005 for the Athens region is 0.35 (Kaskaoutis et al., 2007). From the same dataset Kosmopoulos et al. (2008) concluded that the coarse-mode particles exhibit much stronger interannual and seasonal variability compared to the urban/industrial aerosols.

Numerous spikes in AOD are encountered throughout the whole measurement period (Fig. 1) and are associated either with local sources of particles or enhanced aerosol load-
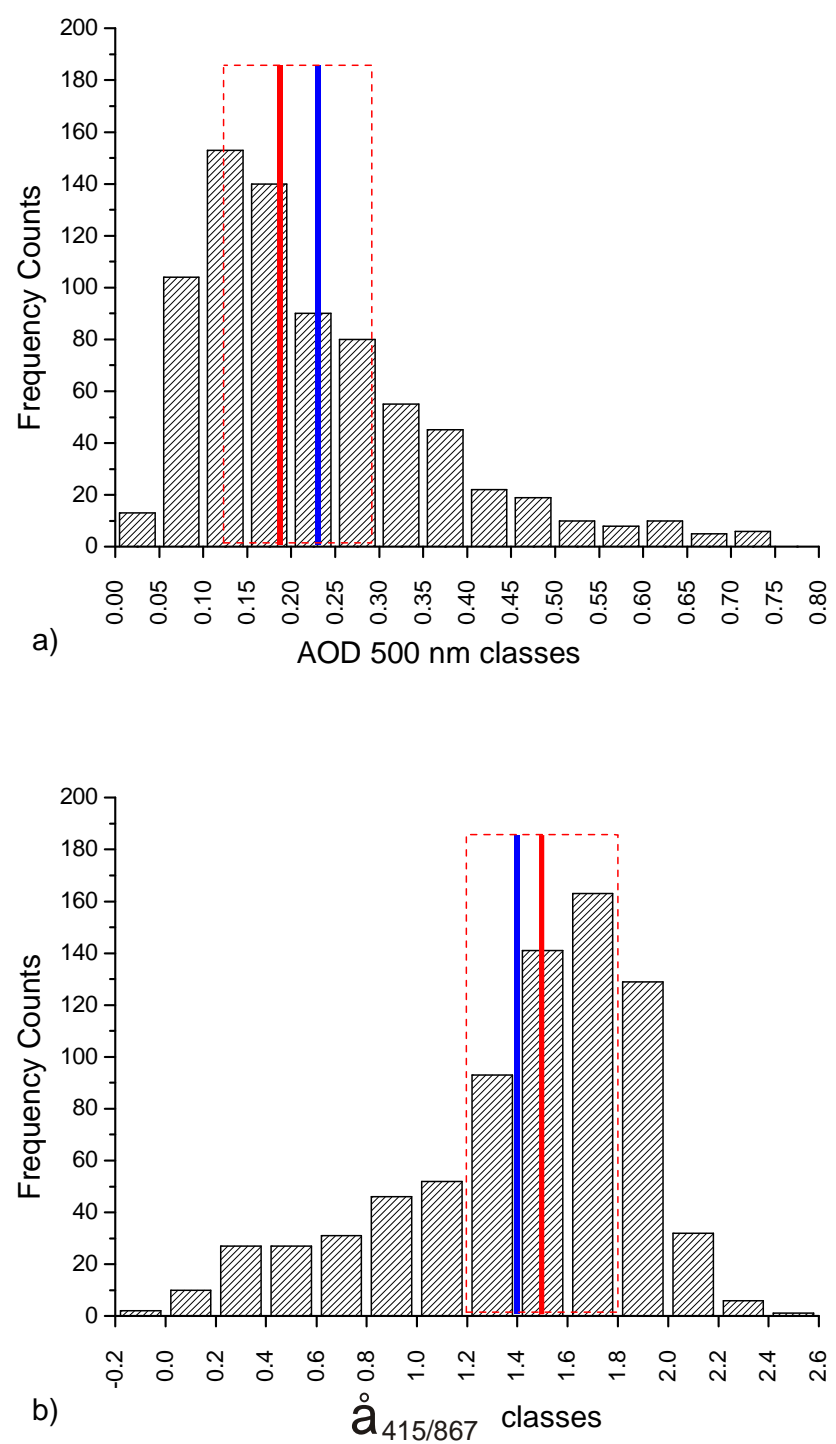

Fig. 2. Frequency distributions of the daily: (a) AOD averages and (b) the Ångström coefficient over Athens, for the period 20062008. The blue line corresponds to the average of the daily values. The red continuous line represents the median and the red dashed box delimits the 1 st and 3rd quartiles, respectively.

ings due to transport. Periods with increased frequency of episodes are clearly illustrated in the monthly values, by large standard deviation bars and divergence between average and median monthly values. The same pattern is seen for a, with the majority of the values being around the median of 1.5 (relatively fine aerosols), indicative of the urban characteristics of Athens' environment. However, most peaks in AOD (especially those $>0.6$ ) are related to low å , indicating the significant contribution of coarse aerosols to the elevated aerosol loadings over Athens (Fig. 3).

On a seasonal basis, maximum AODs are encountered in spring with a peak in April and a monthly average value of 0.35 , in coincidence with the minimum å of 1.2 (Fig. 4). 


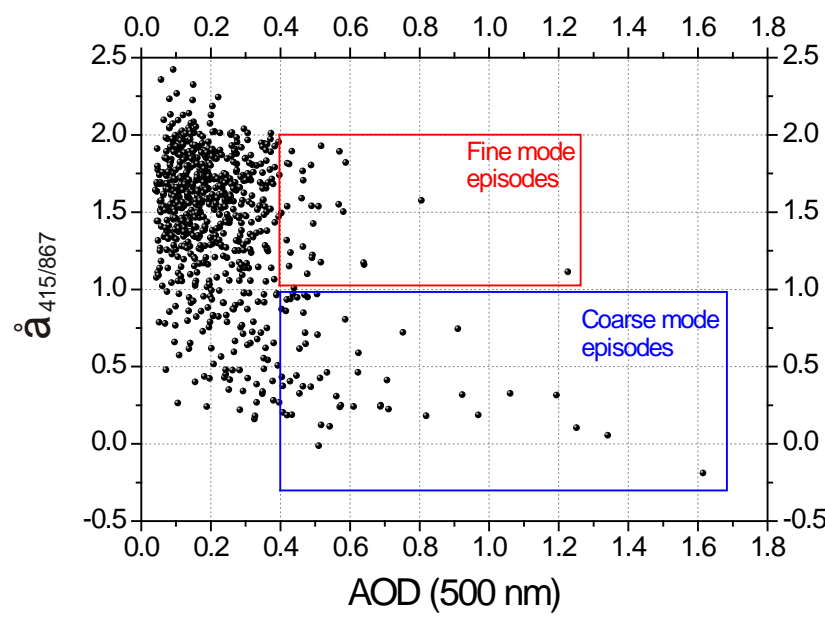

Fig. 3. AOD versus the Ångström coefficient for the period 20062008. High AOD cases (>0.4) of fine and coarse particles, respectively, have been denoted.

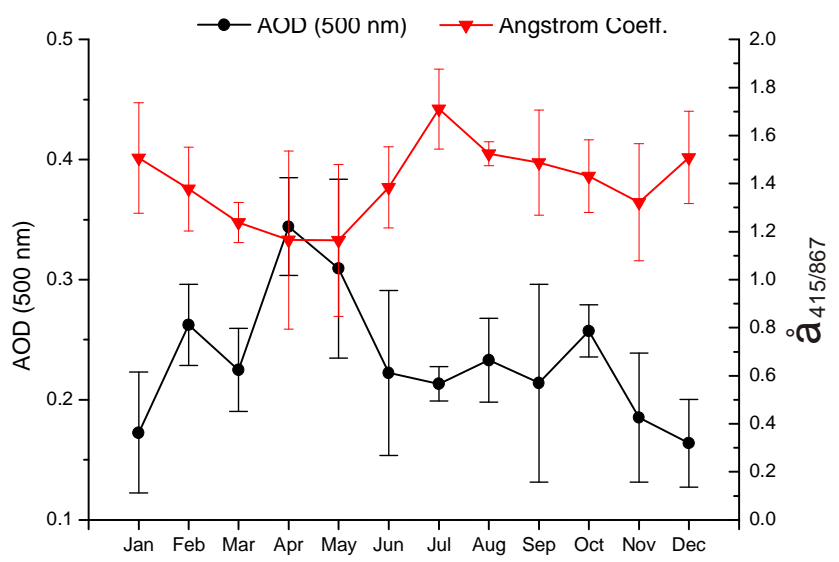

Fig. 4. Annual cycles of AOD at $500 \mathrm{~nm}$ and the Ångström coefficient. Values are calculated as averages of daily means for each month for the period 2006-2008 and the bars are the respective standard deviations.

Minimum AODs are found in the period of November to January (0.16-0.19), with moderate values of å (1.3-1.5), while, during the rest of the period, AODs show a plateau around the average value. å reaches its maximum level (1.7) in July. The seasonal pattern in Athens agrees well with that of the Aegean Sea presented by Koukouli et al. (2010; see their Fig. 5). By comparing the seasonal patterns along a northsouth axis, it can be deduced that the pattern is comprised of two modes, a spring mode reflecting dust transport from the Sahara and a summer mode reflecting continental (Balkans and central-east Europe) sources of pollution, in combination with the dominance of northerly winds in the area, the so-called Etisians. During summer, the build up of particles due to intense photochemical processes, favoured by high temperature and insolation, contributes to the summer maxi- mum mode, in a way that reflects the geographical spread of particle precursor sources and transport processes. Overall, the location of each site along the aforementioned axis and thus the distance from these distinct source areas, defines the observed seasonal pattern at each site, together with other local characteristics or sources. Thus, the observed seasonality in Athens depicts the significant role of dust transport from the Sahara mainly during spring, which brings considerable quantities of coarse dust particles over the Eastern Mediterranean, influencing aerosol loadings as well as surface levels of particulate matter (e.g. Gerasopoulos et al., 2006).

\subsection{Diurnal variation}

We have investigated the diurnal variation of AOD and a on a mean annual and seasonal basis. All observations for a single day are expressed as a percentage departure from the monthly mean. Computed percentages were averaged at half-hour intervals during daylight. Each half-hour average consists of at least 10 min of observations, under the assumption that no significant changes in AOD levels are consistently expected in such a short period, and that a day should have at least $5 \mathrm{~h}$ of available data. We present the diurnal variability of AOD at $500 \mathrm{~nm}$ and å in Fig. 5 .

There is a clear diurnal cycle for both AOD and å during the 2006-2008 period. In particular, AOD is lower in the morning, increases until midday and reaches an afternoon plateau (Fig. 5a). The diurnal departure of AOD from the monthly mean ranges from $-8 \%$ to $6 \%$, with consistent repeatability for the different years (from $-10 \%$ to $10 \%$ ). The average diurnal increase of $14 \%$ corresponds to a 0.03 change in average AOD at $500 \mathrm{~nm}$. This main pattern is more or less reproduced during the different seasons (Fig. 5b). Three points are worth noting: (i) The steep morning increase in autumn which then decreases in the afternoon, with diurnal departures in the range from $-19 \%$ to $24 \%$, (ii) The clear midday maximum in winter, and (iii) The noisy pattern in spring due to the presence of dust storm episodes. The large departures in autumn are mainly due to the relatively lower AOD in the morning, whereas the mid-day peak, in absolute terms, is equal to that encountered in summer. Smirnov et al. (2002) report similar diurnal variability at sites influenced by local urban/industrial sources, with AOD steadily increasing throughout the day, reaching a maximum in the afternoon. For sites relatively close to ours, this increase is less than $10 \%$ (Ispra, Italy) or between $10 \%$ and $15 \%$ (Rome and Bucharest), and in all cases comparable with the mean increase of $14 \%$ we find in Athens.

A distinct diurnal pattern is also revealed for å (Fig. 5c). Year round, low å values are encountered in the morning, steadily increasing towards evening, when they stabilise to a plateau value around 1.65 . The pattern appears repeatable during the 3 years of this study. Less variability and smaller increase is observed in autumn, indicating less variable size of the aerosols. In winter and spring the annual pattern is 

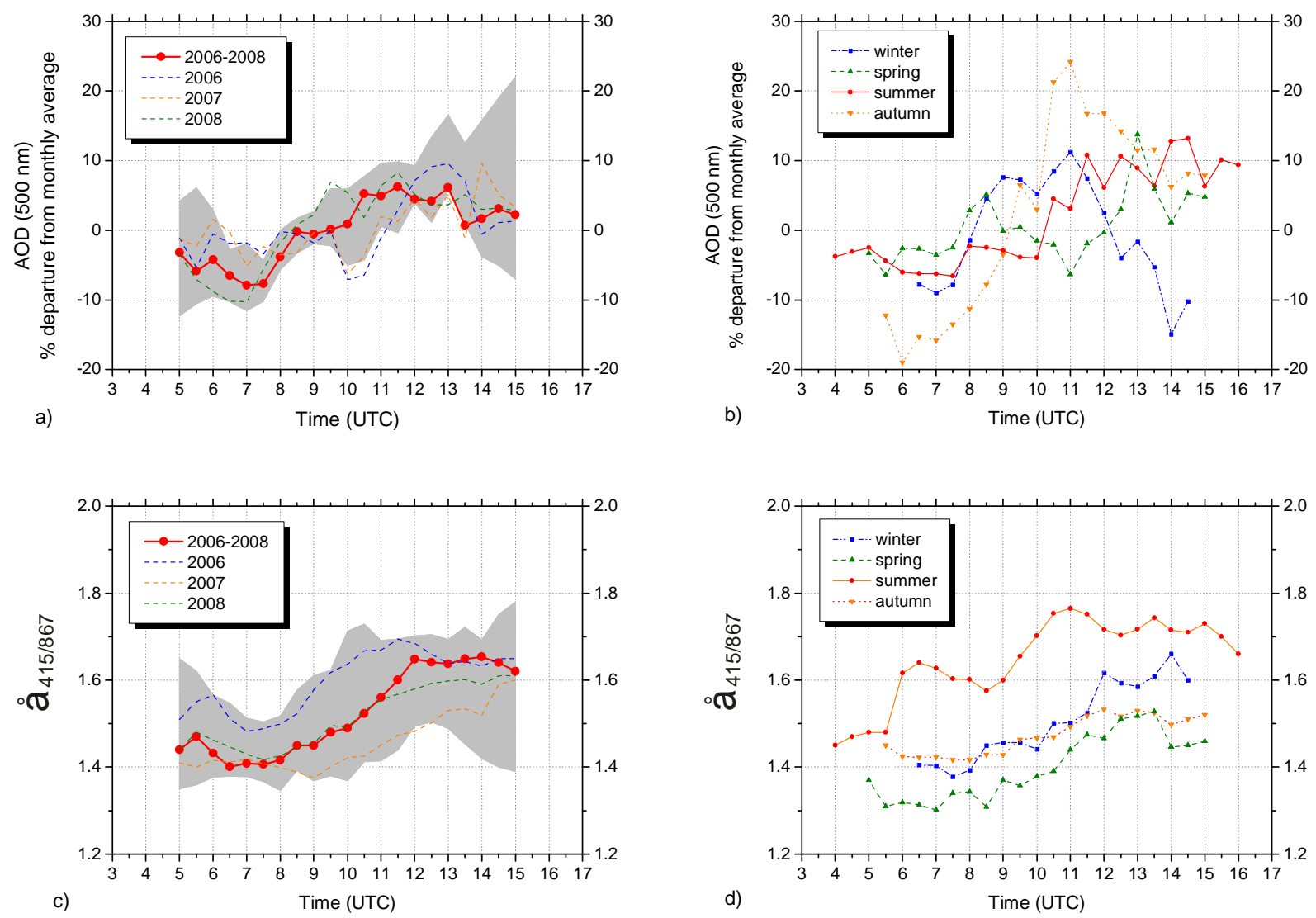

Fig. 5. Diurnal variation of AOD at $500 \mathrm{~nm}$ and the Ångström coefficient. All values are expressed by medians and for AOD the percentage departure of each half-hour point from the monthly mean is given. In panels (a) and (c) the diurnal cycles are provided on an annual basis for the whole period and separately for each year, while the gray zone represents the inter-quartile range of the monthly median departures at the specific time (for the Ångström coefficient we use absolute values instead of percentage departures). In panels (b) and (d) the diurnal cycles are shown for each season separately.

followed, however spring values are lower than winter by an average of $6 \%$ (about 0.1 ), indicating the presence of coarse dust particles in the area. Finally, in summer a is much higher and its diurnal variability coincides with that of AOD, indicating the presence of finer particles.

The increase in both AOD and a during the day seems to be due to a combination of two factors: aerosol sources/processes in urban environments and local scale transport. The station is located to the east of the city centre and local industrial sources are situated at the western part of Athens. Automobile emissions peak in the morning and are likely the major source of primary particles in the city. These facts, when combined with the prevailing local meteorology can explain the increasing tendency in AOD and å. Wind speed and wind direction data from the closest meteorological station (not shown) indicate a year-round wind speed enhancement from early morning to 10:00-11:00 UTC. The dominant wind direction at the station in spring and summer indicates westerly flow, placing the station under the influence of typical urban sources. During autumn and winter, winds are from the NW in the early morning and change to a westerly direction at about 08:00-09:00 UTC. The prevailing wind direction pattern at the station, combined with the increasing wind speed as an index of local transport and the location of the station in relation to the sources, support the increase of aerosol loading as seen in the AOD and the gradual dominance of finer particles from urban processes as seen in the å.

The above is further strengthened by the diurnal variability of $\mathrm{PM}_{10}$ at the surface. In particular, urban-traffic sites (mostly at the center of the city) present a sharp maximum around 08:00 UTC year round, while suburban stations (most of them at the west part of Athens) show a steady increase after 08:00 UTC and a plateau between 11:00 and 14:00 UTC (Kalabokas et al., 2010). The role of sea breeze circulation patterns should also not be disregarded. Overall, during sea breeze days, Athens basin is prone to horizontal recirculation of pollutants (Melas et al., 2005). In particular, during the warm period (except in the cases that the Etisian winds dominate), the sea breeze system reaches its maximum evolution during midday, favoring the advection of sea salt to the north. In this case a concurrent decrease in the å would be expected. 
However, the same process also brings urban particles from the harbor and the city centre towards the suburbs.

\subsection{Major aerosol transport patterns}

Cluster analysis of the HYSPLIT trajectories for the period of January 2006 to December 2008 has revealed 16 distinct synoptic situations transporting air parcels over Athens. These clusters have been grouped into 5 main classes (Fig. 6), whose characteristics are summarised in Table 2 and presented in the following sections.

\subsubsection{Class 1: W-NW-N sector}

This class accounts for $31 \%$ of the total trajectories and includes trajectories that have spent a significant portion of their time over western and central Europe, before arrival over Athens. We have additionally discriminated between short trajectories (Fig. 6, class 1a, 64\% of the class trajectories) and long trajectories (Fig. 6, class $1 \mathrm{~b}, 36 \%$ of the class trajectories), in an attempt to quantify the influence from major continental European aerosol sources, such as urban agglomerations and industrial areas, compared to remote and cleaner source areas.

The average AOD corresponding to short trajectories (Fig. 6, class 1a) is in the range $0.16-0.17$, while å presents a tendency to increase from 1.2 for cluster A (westerly directions) to 1.7 for cluster $\mathrm{C}$ (northerly directions). This tendency of increasing å from west to north is indicative of different source types and mixed types of aerosols at the sector edges, namely sea salt (coarse particles) for cluster A and anthropogenic particles (fine particles) for cluster C. Trajectories in Class 1a are found mostly in summer.

The average AOD corresponding to long and fast trajectories (Fig. 6, class 1b) is in the range 0.12-0.13, while again, å increases going from westerly to northerly directions. The vast majority of these trajectories originate at high altitudes over the Atlantic, bringing the cleanest possible air parcels towards the Eastern Mediterranean. At their latest stage they follow katabatic movement, sweeping in air from nonbackground areas. Even then, the influence is minor since the trajectories from Class $1 \mathrm{~b}$ predominate in winter, when efficient wet-removal and aerosol processes due to cloudy conditions and precipitation are encountered. In addition, efficient ventilation is expected under these circumstances, which contributes to higher dilution of aerosol particles over and around significant sources. In all cases, the average AOD of 0.12-0.13 from this class is the lowest found in this study and can be considered as typical background for Athens in the absence of major transported aerosol loads. Fotiadi et al. (2006) give a mean AOD at $500 \mathrm{~nm}$ of around 0.1 in winter and identify it as near background conditions for Crete, which is, however, dominated by marine aerosols year round. That, in addition to the fact that under N-NW winds Crete is influenced by Athens pollution, makes it difficult to estimate the absolute background in the area and then to discriminate the contribution of local/urban sources of Athens to AOD.

\subsubsection{Class 2: N-NE sector}

Class 2 accounts for $25 \%$ of the total trajectories and represents the N-NE sector, with trajectories coming from Eastern Europe and the Balkans (Fig. 6, class 2). The average AOD corresponding to long and fast trajectories (cluster A) is 0.19 with å equal to 1.6 , characteristics similar to the long and fast trajectories of Class 1 . This cluster accounts for $39 \%$ of the trajectories of this class and presents a narrow summer maximum.

The second cluster of trajectories from the same direction (cluster B), representing 22\% of the trajectories from Class 2, includes short trajectories from over Istanbul and the Black Sea. The average AOD corresponding to this cluster is 0.3 and the average å is 1.5 . It includes $22 \%$ of the trajectories of this class and most of the cases occur during spring and late summer/fall. Istanbul is a megacity in the area (together with Cairo) with a population of approx. 15 million. Such an urban agglomeration, a strong source of anthropogenic particles, is expected to play a significant role in aerosol loadings at regional scales. The average AOD of this cluster is $60 \%$ higher than for cluster A from the same direction and more than double compared to the typical Athens winter background of 0.12 , while the average å (1.5, see Table 2) indicates mixing with marine aerosols over the Aegean Sea. Another significant source from the same direction is the extended area of biomass burning around the north coast of the Black Sea, mainly during summer, which may contribute significantly to AOD (e.g. Balis et al., 2003; Sciare et al., 2008). Both biomass burning and pollution contributions are considered to be episodes rather than a constant influence, a fact illustrated by the enhanced standard deviation of the average AOD, compared to the rest of the clusters of Classes 1 to 3 (see Table 2).

Finally, the third cluster of trajectories (cluster C) of Class 2 , accounts for $39 \%$ of this class and has an average AOD of 0.25 and an average å of 1.7. The high å of this cluster is possibly representative of very fine particles from power plants in the Balkans (Zerefos et al., 2000).

\subsubsection{Class 3: W sector}

The third most frequent class is Class 3 representing $22 \%$ of the total trajectories (Fig. 6, class 3). This class includes air masses arriving from the west, equally distributed between long and short trajectories. The average AOD corresponding to the long trajectories (cluster $\mathrm{A}$ ) is 0.21 and the average å is 1.4. This cluster mainly brings air masses from above the Mediterranean, enriched in marine aerosols, and in some cases it may include continental air masses from the south part of the Iberian and the Italian peninsulas. The contribution of fine aerosols from biomass burning from 

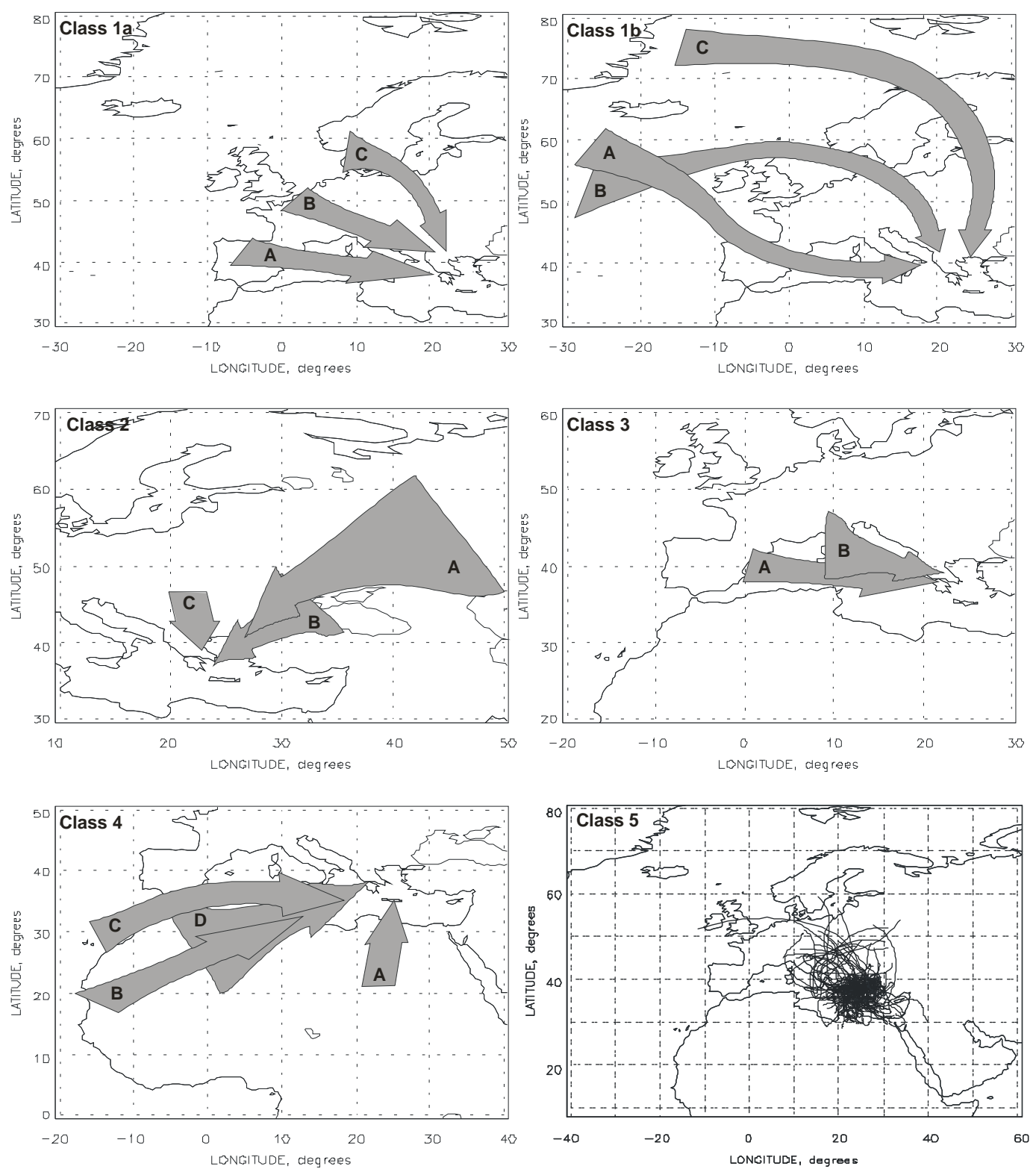

Fig. 6. Cluster analysis of HYSPLIT trajectories for the period 2006-2008. 16 distinct synoptic set ups were grouped into 5 main classes by means of sectoral direction. Arrows follow the direction of the cluster centroid; where feasible, the width of the arrow is representative of the scatter of the trajectories around the calculated centroid.

forest fires, typically detected in summertime in the Iberian and Italian Peninsulas, should also be considered (e.g. Elias et al., 2006; Basart et al., 2009). For short trajectories from the west (cluster B), enhanced average AODs are seen (0.27). These short trajectories are possibly coupled with conditions that favour pollution accumulation and moreover they are partly displaced to the NW thereby sweeping polluted air masses from the Po valley industrial area towards the east, mainly during summer.

\subsubsection{Class 4: $\mathrm{S}$ sector}

The south sector, Class 4 , is related to the highest aerosol loadings over the area, since it includes the transport of dust particles from desert and arid locations of North Africa. Dust transport pathways towards the Eastern Mediterranean, both in the horizontal and in the vertical, have been reported in a number of studies (e.g. Kalivitis et al., 2007; Amiridis et al., 2005; Giannakaki et al., 2010). Our cluster analysis has revealed the three major paths and also a cluster of trajectories with less contact to the African continent (Fig. 6, class 4). 
Table 2. Mean AOD and Ångström coefficient (å) per trajectories cluster.

\begin{tabular}{|c|c|c|c|c|c|c|}
\hline & $\%$ Appearance & $\begin{array}{l}\text { Traj. Characteristic and/or } \\
\text { Potential Source Influence }\end{array}$ & $\begin{array}{c}\text { Main } \\
\text { Direction }\end{array}$ & $\begin{array}{l}\% \text { Appearance } \\
\text { in class }\end{array}$ & Mean AOD & Mean å \\
\hline \multirow[t]{6}{*}{ Class 1} & $31 \%$ & Short, W-Central Europe & $\mathrm{W}$ & & $0.16 \pm 0.06$ & $1.2 \pm 0.4$ \\
\hline & & & NW & $64 \%$ & $0.16 \pm 0.11$ & $1.5 \pm 0.4$ \\
\hline & & & $\mathrm{N}$ & & $0.17 \pm 0.11$ & $1.7 \pm 0.3$ \\
\hline & & Long-fast, Atlantic & $\mathrm{W}$ & & $0.13 \pm 0.10$ & $1.4 \pm 0.4$ \\
\hline & & & NW & $36 \%$ & $0.13 \pm 0.09$ & $1.7 \pm 0.3$ \\
\hline & & & $\mathrm{N}$ & & $0.12 \pm 0.05$ & $1.6 \pm 0.4$ \\
\hline \multirow[t]{3}{*}{ Class 2} & $25 \%$ & Long-fast, E. Europe & NE & $39 \%$ & $0.19 \pm 0.10$ & $1.6 \pm 0.3$ \\
\hline & & Short, Istanbul/Black Sea & NE & $22 \%$ & $0.30 \pm 0.17$ & $1.5 \pm 0.3$ \\
\hline & & Short, Balkans & $\mathrm{N}$ & $39 \%$ & $0.25 \pm 0.12$ & $1.7 \pm 0.3$ \\
\hline \multirow[t]{2}{*}{ Class 3} & $22 \%$ & Short, stagnant Mediterranean/Po valley & $\mathrm{W}$ & $51 \%$ & $0.27 \pm 0.15$ & $1.5 \pm 0.4$ \\
\hline & & Long, Mediterranean & $\mathrm{W}$ & $49 \%$ & $0.21 \pm 0.13$ & $1.4 \pm 0.4$ \\
\hline \multirow[t]{5}{*}{ Class 4} & $16 \%$ & Short, dust & $\mathrm{S}$ & $11 \%$ & $0.41 \pm 0.40$ & $0.6 \pm 0.5$ \\
\hline & & Long, dust via Tunis gulf & SW & $4 \%$ & $0.36 \pm 0.22$ & $0.4 \pm 0.3$ \\
\hline & & Long, dust/time over Mediterranean & W-W & $11 \%$ & $0.42 \pm 0.29$ & $0.6 \pm 0.4$ \\
\hline & & Mixed of the two above & W-SW & $37 \%$ & $0.34 \pm 0.27$ & $0.7 \pm 0.4$ \\
\hline & & Short, less African contact & SW & $37 \%$ & $0.29 \pm 0.20$ & $1.1 \pm 0.5$ \\
\hline Class 5 & $6 \%$ & Stagnant conditions & - & - & $0.34 \pm 0.21$ & $1.2 \pm 0.5$ \\
\hline
\end{tabular}

The first cluster of trajectories (cluster A) arrives over Athens directly from the south, transporting dust particles from extended arid areas in Libya and Egypt. The direction of this cluster centroid also points to the Bodélé Depression in southern Chad, which is among the major dust sources as seen from space measurements (e.g. Engelstaedter and Washington, 2007), with dust storms occurring on average about 100 days per year (Washington et al., 2006). The trajectories of this cluster traverse the shortest distance over water before reaching Greece, compared to the rest of the clusters that bring dust from Africa. The average AOD for this cluster, which accounts for $11 \%$ of the trajectories of this class, is 0.41 with an å of 0.6 and as in all clusters of this class, the maximum frequency of occurrence is in spring.

The second cluster of trajectories (cluster B) includes only $4 \%$ of the south sector cases and brings air masses from the heart of the Sahara in Mali and Mauritania, via the gulfs of Sirte and Tunis. The reason for including it as a separate cluster is that apart from the high aerosol loadings (average AOD 0.36) it is related to the lowest å, equal to 0.4. Another $11 \%$ of the trajectories (cluster $\mathrm{C}$ ) is related to dust mobilised over the W-NW parts of Sahara and then transported to the east having travelled all along the Mediterranean Basin. Even though strong mixing with the marine environment is highly expected, as well as gravitational settling of the heavier particles, these trajectories still retain high loadings of aerosols with average AOD equal to 0.42 and å of 0.6 .

Finally, most of the trajectories fall into cluster D (74\%) which is a mixture of clusters B and C, both in origins of air masses and characteristics. The average AOD corresponding to this cluster is 0.34 and the average å is 0.7. However, half of these trajectories show less contact with the African continent and as a consequence have a lower AOD (0.29) and higher å (1.1).

\subsubsection{Class 5: stagnant conditions}

The final class (Fig. 6, class 5) includes short trajectories of local influence mainly found during stagnant conditions. Such conditions favour the impact of local sources and the accumulation of aerosols in the area. The average AOD of the class is 0.34 and the average $a$ is 1.2 , indicating significant presence of coarse particles, either resuspended dust from the vicinity or marine aerosols from the Aegean Sea.

As a follow up of the analysis for each distinct class we have attempted to calculate the contribution of each class to the average AOD of 0.23 . Taking into account both the percentage appearance of each class and the respective AOD value, all major classes, initially grouped due to the direction and characteristics of the air mass trajectories, are found to contribute equally (20-25\%), except Class 5 which has a contribution of about $10 \%$. Interesting findings however are revealed when grouping the various clusters by means of qualitative characteristics such as the distance range and type of the source. This is shown in Fig. 7 where the new groups are: sources from continental Europe (including the short trajectory clusters of Class 1 and the long-fast ones from Class 2), regional/local influence (including the 


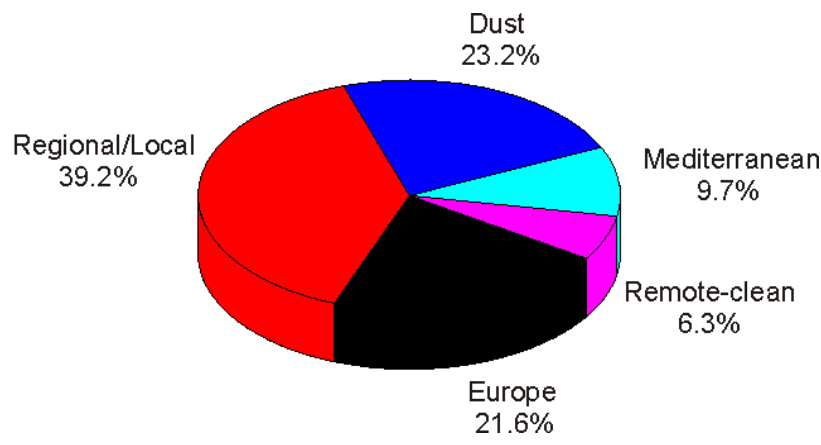

Fig. 7. Contribution of discrete source areas to the average AOD taking into account the percentage time of influence and the respective AOD level.

impact from neighbouring urban/industrial sites such as the Balkans, the Po valley, Istanbul and nearby biomass burning areas, but also local sources under stagnant conditions), dust, the Mediterranean Basin environment and finally remote, clean areas (those cluster originating over the Atlantic). The greatest contribution comes from regional and local sources accounting for almost $40 \%$ of the average AOD during the whole period of study. Another important contribution (23\%), despite the relatively lower percentage of time influence (16\% see Table 2), is dust from Africa, whereas the rest of Europe contributes another 22\%.

\subsection{Comparison between ground based and satellite derived AODs}

In order to compare the AODs from the MFR to the MODIS derived AODs for Athens, we have first calculated the AOD at $550 \mathrm{~nm}$. For that we used Ångström's (1929) empirical formula and the å calculated from 415 and $867 \mathrm{~nm}$. Smirnov et al. (2002), using data from AERONET, found that the daily mean AOD values are very close to the mean values in the time window frame within \pm 30 min of the MODIS overpass. However, this depends on the diurnal variability of the individual site.

For this reason, two data sets were produced from the MFR measurements for the purpose of the comparison, one with daily averages ( $\left.\mathrm{AOD}_{\mathrm{MFR}-\text { daily }}\right)$ and one with the 30 min averages centred around the time of the satellite overpass over Athens (AOD ${ }_{\text {MFR-ovps }}$ ) at around 09:30 UTC. The overpass time coincides with the middle of the diurnal increasing branch (see Fig. 5a), thus the two time series are expected to be significantly correlated. Indeed, the calculation of the regression line between the two data sets gives a slope of 1.02 , an intercept of 0.004 and $R^{2}$ equal to 0.89 , after the exclusion of only 10 points for which the overpass averages exceed the daily averages by $40-150 \%$, characteristic of very spiky episodes. The correlation with MODIS data is better with the use of the daily averages dataset $\left(R^{2} 0.65\right.$ vs. 0.55$)$, thus we use the AOD MFR-daily for further analysis.
The average AOD at $550 \mathrm{~nm}$ during the common days ( $N=740$ ) between the two data sets is $0.19 \pm 0.13$ from the MFR while from MODIS it is $0.22 \pm 0.15$. The regression line between the two is shown in Fig. 8. Both the slope and the intercept are in agreement with similar comparisons between MODIS and AERONET data (e.g. Remer et al., 2008; Papadimas et al., 2008). The insert panel in Fig. 7 shows the ratio $\mathrm{AOD}_{\mathrm{MODIS}} / \mathrm{AOD}_{\mathrm{MFR}}$, highlighting that throughout the year the deviation between MODIS with the ground based data lies within $\pm 10 \%$ (there is underestimation in winter and an overestimation in the transition periods), but in late summer and September MODIS may overestimate AOD values on average $30 \%$. As a consequence, the main seasonal pattern is reproduced by MODIS, namely the spring maximum; however summer levels are relatively enhanced and appear as a secondary maximum.

The relation between MFR and MODIS has also been investigated in AOD bins of 0.1 , with the highest AOD bin typically representing fewer observations than the other bins, however no particular pattern was revealed.

Our results are in general agreement with El-Metwally et al. (2010), who showed that MODIS generally tends to overestimate the sunphotometer reference optical depths over the city of Cairo, Egypt. They find a fairly good agreement in winter (ratio close to 1, but still overestimation), and an overestimation of the AOD by MODIS larger than $40 \%$ in spring and autumn (still high in summer months). They have attributed this tendency to the inappropriate adaption of the aerosol model for inverting the MODIS radiances measurements in the desert dust and biomass burning periods, and a possible worse parameterization of the reflectance of the desert-like soil surface.

In Athens' case, the comparison results are somewhat better, since the second reason, above, is not the cause, however, indeed overestimation coincide with periods of dust transport (around $10 \%$ in spring) or smoke transport from biomass burning (around 30\% in late summer).

\subsection{Contribution of fine and coarse particles to AOD}

AOD and a give information on the columnar aerosol loading over an area and a first indication of the particle sizes. It is obvious that for more information on the composition of this aerosol, full chemical analysis is needed, which however describes the aerosol composition only at the surface. Gobbi et al. (2007) have presented a graphical framework for classifying additional aerosol properties using AOD observations. Their method relies on the combined analysis of a and its spectral curvature, which allows for the inference of fine mode aerosol size and fractional contribution to the total AOD. In addition, it permits the separation of AOD growth by aerosol humidification and/or coagulation (aging), from AOD growth by inclusion of coarse mode particles or cloud contamination. It should be noted that for $\mathrm{AOD}<0.10$, the errors associated to å and å difference are 


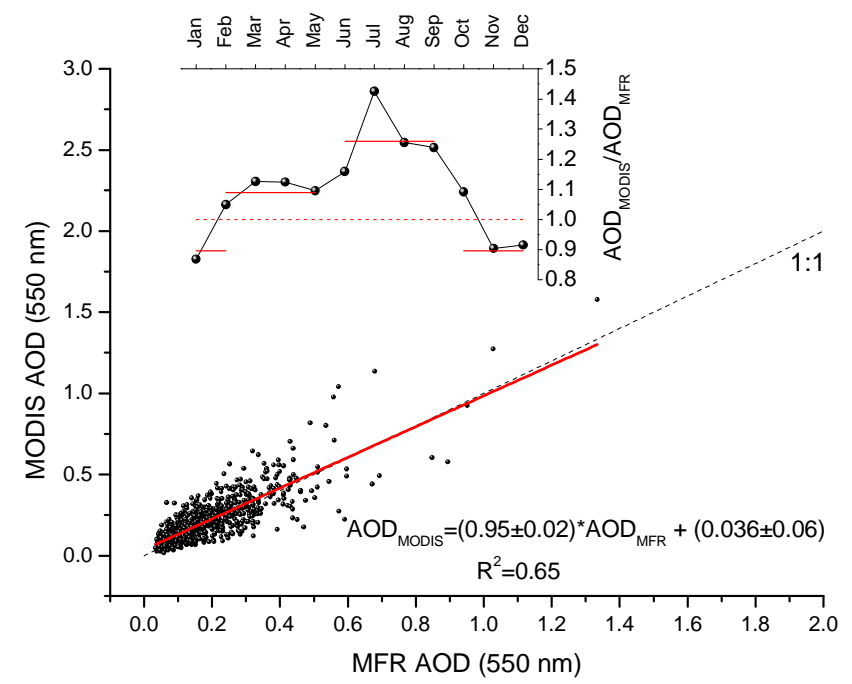

Fig. 8. Scatter plot between AODs from the MFR versus MODIS derived AODs over Athens. The red thick line is the regression line between the two data sets. The internal panel presents the annual cycle of the AOD $_{\text {MODIS }} /$ AOD $_{\text {MFR }}$ ratio, the red dashed line shows the unity value of the ratio, while the red thin lines corresponds to the average between months of close ratio values.

$\sim 20 \%$ and $\sim 50 \%$, respectively. For this reason, AOD $>0.15$ are used in Gobbi et al. (2007), in order to avoid errors $>30 \%$. Here we have used the AOD retrievals from the MFR measurements to classify the aerosol properties as a function of $\mathrm{a}_{440 / 870}$ and the difference of $\mathrm{a}_{440 / 675}-\AA_{6} 675 / 870$, for bimodal, lognormal size distributions. This graphical method is used to visually investigate the contribution of fine aerosol to the AOD (through the fine mode fraction) and the size of the fine aerosols (Fig. 9). The black solid lines account for a fixed effective radius $\left(R_{\mathrm{f}}\right)$ of the fine mode and the dashed lines for a fixed fraction contribution $(\eta)$ of the fine mode to the AOD. For the three years of measurements analyzed for Athens, it can be seen that a variety of fine mode fractions can be found for typical AOD values, with an average fine mode $R_{\mathrm{f}}$ of about $0.12 \mu \mathrm{m}$. A great number of cases with å lower than 0.5 demonstrates the high impact of coarse particles at the site. As already shown in the cluster analysis section, most of the cases with maximum AODs are characterized by the presence of dust particles from the Sahara. Characteristically, $23 \%$ and $44 \%$ of the cases with AOD $>0.3$ are related to $\stackrel{\circ}{<}<0.5$ and $\stackrel{\circ}{<}<$, respectively. In Fig. 9 we can distinguish two cases with high AOD combined with low å: (a) $\eta<30 \%$ and $R_{\mathrm{f}} \sim 0.12 \mu \mathrm{m}$ and (b) $\eta<50 \%$ and $R_{\mathrm{f}}>0.20 \mu \mathrm{m}$. In the first case, the fact that $\mathrm{a}_{440 / 675^{-}}$ $\mathrm{a}_{675 / 870}>0$ indicates the presence of two separate particle modes, suggesting dust mixed with fine anthropogenic par-

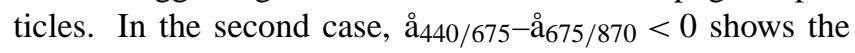
dominance of one mode, which is associated to coarse dust particles given that in the part of Fig. 9 limited by $\eta<50 \%$ and $R_{\mathrm{f}}>0.20 \mu \mathrm{m}$, ̊̊ is lower than 0.5 .

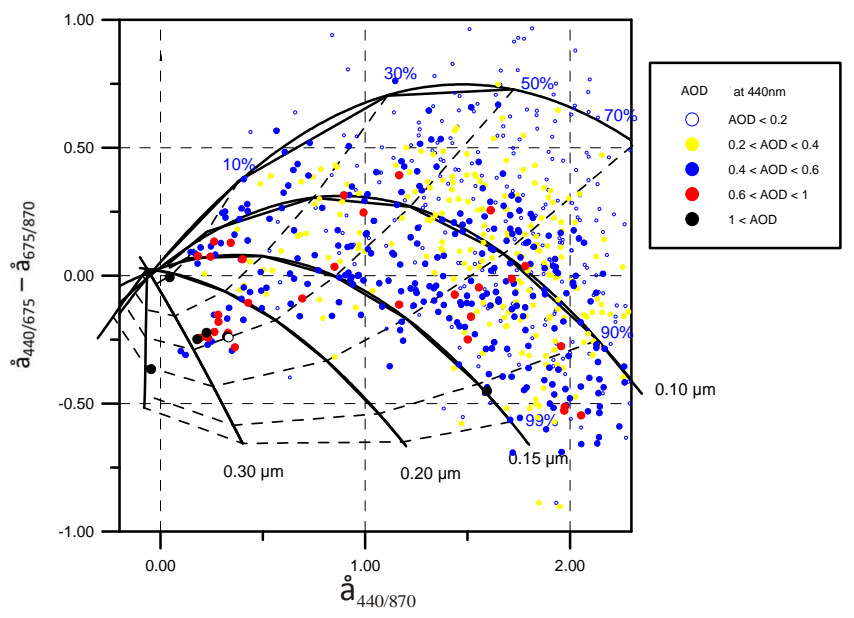

Fig. 9. Ångström coefficient difference $\left(\stackrel{̊}{4}_{440 / 675}-\AA_{675 / 870}\right)$ as a function of å440/870 and AOD at $440 \mathrm{~nm}$ over Athens, for bimodal, lognormal size distributions. The black solid lines account for a fixed effective radius $\left(R_{\mathrm{f}}\right)$ of the fine mode and the dashed lines for a fixed fraction contribution $(\eta)$ of the fine mode to the AOD.

Basart et al. (2009) provided an atmospheric aerosol characterization for the Mediterranean among other areas, based on AERONET data for the period 1994-2007, applying the same graphical method. The closest sites to Athens presented in this work are Thessaloniki to the north and Crete to the south. In the first case high AODs mainly cluster in the fine mode corresponding to $\eta \cong 85 \%$ and $R_{\mathrm{f}} \cong 0.13 \mu \mathrm{m}$, representative of fine particles from local and regional urban/industrial sources. AOD growth is linked to increased extinction due to both, coagulation-aging and hydration. In Crete, the data shows high AODs, mainly clustering in the coarse mode corresponding to $\eta<30 \%$, with particles related to long-range transport of mineral dust from the south. The pattern revealed for Athens, which is located in the middle of the two other sites, shows great similarities to the one recorded for Rome, Italy (Gobbi et al., 2007; Basart et al., 2009). Both cities are located at the middle of the Mediterranean Basin in the north-south direction and at about the same distance from the main sources of particulate matter in the area, e.g. dust from Sahara and anthropogenic particles from continental Europe. Moreover, both cities have similar populations and are influenced by distinct sources of pollutions from the north, namely Istanbul, Black Sea biomass burning and Balkan power plants on one hand, and the Po valley on the other hand.

\section{Conclusions}

Three years of observations (2006-2008) of the Aerosol Optical Depth (AOD) in the urban environment of Athens, in the eastern Mediterranean, were analysed and presented in this work. This is the first long term, ground based data 
set available for this area, which is being continued by the newly established "Athens-NOA" AERONET station at the same location. The main conclusions of this work can be summarized as follows:

- The daily average AOD at $500 \mathrm{~nm}$ over Athens is $0.23 \pm 0.17$ and the Ångström coefficient (å) calculated between 415 and $867 \mathrm{~nm}$, is $1.41 \pm 0.48$. Similar values are found along a north-south axis in the eastern Mediterranean Basin, indicative of strong sources of particulate matter in the area, which contribute to the degradation of air quality at regional scale.

- The position of Athens in the middle of the above mentioned axis defines the annual cycle of AOD and å. The patterns observed in Athens appear to be closer to that of the southern stations, which exhibit a pronounced spring mode, reflecting dust transport from the Sahara, rather than that of northern stations, where the summer mode prevails, reflecting continental (Balkans and central-east Europe) sources of pollution.

- A diurnal cycle of AOD typical for urban sites is found in Athens, with AOD steadily increasing throughout the day. A similar increase is observed in å, and both patterns are shown to be a combination of aerosol sources/processes in urban environments and local scale transport.

- Three general points are concluded from the trajectory cluster analysis: (i) The variation of both aerosol columnar loadings and size are controlled by well distinguished regional rather than local sources of pollution, (ii) Short trajectories versus long trajectories, from the same direction, are responsible for more efficient particle transport, since their motion is closer to the surface, thus sweeping polluted air masses from within the boundary layer, (iii) A tendency of increasing å from west to north-northeast exists, indicative of different types of sources and mixed types of aerosols at the sector edges, namely sea salt (coarse particles) for clusters close to the Mediterranean Sea and anthropogenic particles (fine particles) for continental clusters.

- The greatest contribution to the annually averaged AOD comes from regional and local sources and accounts for almost $40 \%$. Dust from desert and arid locations of North Africa has an important contribution (23\%) despite the lower frequency of occurrence, whereas the rest of continental Europe contributes another $22 \%$.

- The cleanest conditions are found under N-NW winds and long trajectories that originate from high altitudes over the Atlantic. An average AOD of 0.12-0.13 can be considered as typical background for Athens, in the absence of major transported aerosol loads, and it is mainly encountered during winter.
- Maximum aerosol loads (AOD of 0.34-0.42) are found in spring in conjunction with low å values, representing the significant contribution of transported dust particles. The second most important source area of high aerosol loadings originates from the direction of the Istanbul metropolitan area and the extended areas of biomass burning around the north coast of the Black Sea. They prevail only $6 \%$ of the time resulting in an AOD of about 0.3 . Point sources spread through the Balkans (mostly power plants) also seem to cause elevated AODs (0.25) associated with finer particles mainly during summer.

- The comparison between MFR and MODIS revealed that the main seasonal pattern is reproduced by MODIS, namely the spring maximum, however summer levels from MODIS are relatively enhanced and appear as a secondary maximum.

- The contribution of fine particles to typical AOD ranges widely from $10 \%$ to $90 \%$, indicative of a mixture of aerosol types over Athens. A predominant number of cases with å lower than 0.5 demonstrates the high impact of dust particles at the site. Dust particles can either be present without altering the local fine mode size, or they can be associated with fine mode growth mechanisms at the same time.

This analysis is intended to provide data on the climatological aspects of aerosol loadings over an urban environment in the eastern Mediterranean, based on ground measurements. Such data sets are essential for the validation of satellite products, which can then be used for long term climatic studies. However, for the detailed identification and apportionment of sources, chemical composition of aerosols is needed. With such information it will then be feasible to estimate the contribution of distinct sources at local or regional scales versus the pollution from urban activities, in an area characterized by diverse mixtures of aerosols and processes.

Acknowledgements. The research leading to these results has received funding from the project CITYZEN of the European Union's Seventh Framework Programme (FP7/2007-2013) under Grant Agreement no. 212095.

Edited by: N. Mihalopoulos

\section{References}

Amiridis, V., Balis, D. S., Kazadzis, S., Bais, A., Giannakaki, E., Papayannis, A., and Zerefos, C.: Four-year aerosol observations with a Raman lidar at Thessaloniki, Greece, in the framework of EARLINET, J. Geophys. Res., 110, D21203, doi:10.1029/2005JD006190, 2005.

Amiridis, V., Kafatos, M., Perez, C., Kazadzis, S., Gerasopoulos, E., Mamouri, R. E., Papayannis, A., Kokkalis, P., Giannakaki, E., 
Basart, S., Daglis, I., and Zerefos, C.: The potential of the synergistic use of passive and active remote sensing measurements for the validation of a regional dust model, Ann. Geophys., 27, 3155-3164, doi:10.5194/angeo-27-3155-2009, 2009.

Andreae, T. W., Andreae, M. O., Ichoku, C., Maenhaut, W., Cafmeyer, J., Karnieli, A., and Orlovsky, L., Light scattering by dust and anthropogenic aerosol at a remote site in the Negev desert, Israel, J. Geophys. Res., 107, 4008, doi:10.1029/2001JD900252, 2002.

Ångström, A.: On the atmospheric transmission of sun radiation and on dust in the air, Geogr. Ann. 12, 130-159, 1929.

Balis, D., Amiridis, V., Zerefos, C., Gerasopoulos, E., Andreae, M. O., Zanis, P., Kazantzidis, A., Kazadzis S., and Papayannis, A.: Raman lidar and sunphotometric measurements of aerosol optical properties over Thessaloniki, Greece during a biomass burning episode, Atmos. Environ., 37, 4529-2538, 2003.

Balis, D. S., Amiridis, V., Zerefos, C., Kazantzidis, A., Kazadzis, S., Bais, A. F., Meleti, C., Gerasopoulos, E., Papayannis, A., Matthias, V., Dier, H., and Andreae, M. O.: Study of the effect of different type of aerosols on UV-B radiation from measurements during EARLINET, Atmos. Chem. Phys., 4, 307-321, doi:10.5194/acp-4-307-2004, 2004.

Barnaba, F. and Gobbi, G. P.: Aerosol seasonal variability over the Mediterranean region and relative impact of maritime, continental and Saharan dust particles over the basin from MODIS data in the year 2001, Atmos. Chem. Phys., 4, 2367-2391, doi:10.5194/acp-4-2367-2004, 2004.

Basart, S., Pérez, C., Cuevas, E., Baldasano, J. M., and Gobbi, G. P.: Aerosol characterization in Northern Africa, Northeastern Atlantic, Mediterranean Basin and Middle East from direct-sun AERONET observations, Atmos. Chem. Phys., 9, 8265-8282, doi:10.5194/acp-9-8265-2009, 2009.

Chu, D. A., Kaufman, Y. J., Ichoku, C., Remer, L. A., Tanré, D., and Holben, B. N.: Validation of MODIS aerosol optical depth retrieval over land, Geophys. Res. Lett., 29(12), 8007, doi:10.1029/2001GL013205, 2002.

Dorling, S. R., Davies, T. D., and Pierce, C. E.: Cluster analysis: a technique for estimating the synoptic meteorological controls on air and precipitation chemistry - method and applications, Atmos. Environ. 26A, 2575-2581, 1992.

Draxler, R. R. and Hess, G. D.: An overview of the HYSPLIT_4 modeling system for trajectories, dispersion and deposition, Aust. Meteorol. Mag., 47, 295-308, 1998.

El-Askary, H. and Kafatos, M.: Dust storm and black cloud influence on aerosol optical properties over Cairo and the greater delta region, Egypt, Int. J. of Rem. Sens., 29(24), 7199-7211, 2008.

El-Askary, H., Sarkar, S., Kafatos, K., and El-Ghazawi, T. A.: A multisensor approach to dust storm monitoring over the Nile delta, IEEE T. Geosci. Remote, 41(10), 2386-2391, 2003.

El-Askary, H., Farouk, R., Ichoku, C., and Kafatos, M.: Transport of dust and anthropogenic aerosols across Alexandria, Egypt, Ann. Geophys., 27, 2869-2879, doi:10.5194/angeo-27-28692009, 2009.

Elias, T., Silva, A. M., Belo, N., Pereira, S., Formenti, P., Helas, G., and Wagner, F.: Aerosol extinction in a remote continental region of the Iberian Peninsula during summer, J. Geophys. Res., 111(D14), D14204, doi:10.1029/2005JD006610, 2006.

El-Metwally, M., Alfaro, S. C., Abdel Wahab, M. M., Zakey, A. S., and Chatenet, B.: Seasonal and inter-annual variability of the aerosol content in Cairo (Egypt) as deduced from the comparison of MODIS aerosol retrievals with direct AERONET measurements, Atmos. Res., 97, 14-25, doi:10.1016/j.atmosres.2010.03.003, 2010.

Engel-Cox, J. A., Holloman, C. H., Coutant, B. W., and Hoff, R. M.: Qualitative and quantitative evaluation of MODIS satellite sensor data for regional and urban scale air quality, Atmos. Environ., 38, 2495-2509, 2004.

Engelstaedter, S. and Washington, R.: Atmospheric controls on the annual cycle of North African dust, J. Geophys. Res., 112, D03103, doi:10.1029/2006JD007195, 2007.

Formenti, P., Andreae, M. O., Andreae, T. W., Galani, E., Vasaras, A., Zerefos, C., Amiridis, V., Orlovsky, L., Karnieli, A., Wendisch, M., Wex, H., Holben, B. N., Maenhaut, W., and Lelieveld, J.: Aerosol optical properties and large scale transport of air masses: Observations at a coastal and a semiarid site in the eastern Mediterranean during summer 1998, J. Geophys. Res., 106, 9807-9826, 2001.

Fotiadi, A., Hatzianastassiou, N., Drakakis, E., Matsoukas, C., Pavlakis, K. G., Hatzidimitriou, D., Gerasopoulos, E., Mihalopoulos, N., and Vardavas, I.: Aerosol physical and optical properties in the Eastern Mediterranean Basin, Crete, from Aerosol Robotic Network data, Atmos. Chem. Phys., 6, 53995413, doi:10.5194/acp-6-5399-2006, 2006.

Gerasopoulos, E., Andreae, M. O., Zerefos, C. S., Andreae, T. W., Balis, D., Formenti, P., Merlet, P., Amiridis, V., and Papastefanou, C.: Climatological aspects of aerosol optical properties in Northern Greece, Atmos. Chem. Phys., 3, 2025-2041, doi:10.5194/acp-3-2025-2003, 2003.

Gerasopoulos, E., Kouvarakis, G., Babasakalis, P., Vrekoussis, M., Putaud, J.-P., Mihalopoulos, N.: Origin and variability of particulate matter $\left(\mathrm{PM}_{10}\right)$ mass concentrations over the Eastern Mediterranean, Atmos. Environ., 40(25), 4679-4690, 2006.

Gerasopoulos, E., Koulouri, E., Kalivitis, N., Kouvarakis, G., Saarikoski, S., Mäkelä, T., Hillamo, R., and Mihalopoulos, N.: Size-segregated mass distributions of aerosols over Eastern Mediterranean: seasonal variability and comparison with AERONET columnar size-distributions, Atmos. Chem. Phys., 7, 2551-2561, doi:10.5194/acp-7-2551-2007, 2007.

Gerasopoulos, E., Kokkalis, P., Amiridis, V., Liakakou, E., Perez, C., Haustein, K., Eleftheratos, K., Andreae, M. O., Andreae, T. W., and Zerefos, C. S.: Dust specific extinction cross-sections over the Eastern Mediterranean using the BSC-DREAM model and sun photometer data: the case of urban environments, Ann. Geophys., 27, 2903-2912, doi:10.5194/angeo-27-29032009, 2009.

Giannakaki, E., Balis, D. S., Amiridis, V., and Zerefos, C.: Optical properties of different aerosol types: seven years of combined Raman-elastic backscatter lidar measurements in Thessaloniki, Greece, Atmos. Meas. Tech., 3, 569-578, doi:10.5194/amt-3569-2010, 2010.

Giavis, G. M., Kambezidis, H. D., Sifakis, N., Toth, Z., Adamopoulos, A. D., and Zevgolis, D.: Diurnal variation of the aerosol optical depth for two distinct cases in the Athens area, Greece, Atmos. Res., 78(1-2), 79-92, doi:10.1016/j.atmosres.2005.03.003, 2005.

Gobbi, G. P., Kaufman, Y. J., Koren, I., and Eck, T. F.: Classification of aerosol properties derived from AERONET direct sun data, Atmos. Chem. Phys., 7, 453-458, doi:10.5194/acp-7-453-2007, 
2007.

Griffin, D. W., Kubilay, N., Kocak, M., Gray, M. A., Borden, T. C., and Shinn, E. A.: Airborne desert dust and aeromicrobiology over the Turkish Mediterranean coastline, Atmos. Environ., 41, 4050-4062, doi:10.1016/j.atmosenv.2007.01.023, 2007.

Harrison, L. and Michalsky, J.: Objective algorithms for the retrieval of optical depths from ground-based measurements, Appl. Optics, 33, 5126-5132, 1994.

Harrison, L., Michalsky, J., and Berndt, J.: Automated multifilter rotating shadow-band radiometer: an instrument for optical depth and radiation measurements, Appl. Optics, 33, 5118-5125, 1994.

Hatzianastassiou, N., Gkikas, A., Mihalopoulos, N., Torres, O., and Katsoulis, B. D.: Natural versus anthropogenic aerosols in the eastern Mediterranean basin derived from multiyear TOMS and MODIS satellite data, J. Geophys. Res., 114, D24202, doi:10.1029/2009JD011982, 2009.

IPCC: Intergovernmental Panel on Climate Change, Climate Change 2001: The Scientific Basis, in: Contribution of Working Group I to the Third Assessment Report of the Intergovernmental Panel on Climate, edited by: Houghton, J.T., Ding, Y., Griggs, D. J., Noguer, M., van der Linden, P. J., Dai, X., Maskell, K., and Johnson, C. A., Cambridge Univ. Press, New York, 2001.

IPCC: Intergovernmental Panel on Climate Change 2007: Climate Change 2007: The Physical Science Basis, Summary for Policymakers, Paris, February 2007.

Israelevich, P. L., Levin, Z., Joseph, J. H., and Ganor, E.: Desert aerosol transport in the Mediterranean region as inferred from the TOMS aerosol index, J. Geophys. Res., 107(D21), 4572, doi:10.1029/2001JD002011, 2002.

Jacovides, C. P., Kaltsounides, N. A., Asimakopoulos, D. N., and Kaskaoutis, D. G.: Spectral aerosol optical depth and Ångström parameters in the polluted Athens atmosphere, Theor. Appl. Climatol., 81, 161-167, doi:10.1007/s00704-004-0110-3, 2005.

Kazadzis, S., Bais, A., Amiridis, V., Balis, D., Meleti, C., Kouremeti, N., Zerefos, C. S., Rapsomanikis, S., Petrakakis, M., Kelesis, A., Tzoumaka, P., and Kelektsoglou, K.: Nine years of UV aerosol optical depth measurements at Thessaloniki, Greece, Atmos. Chem. Phys., 7, 2091-2101, doi:10.5194/acp-7-20912007, 2007.

Kalabokas, P. D., Adamopoulos, A. D., and Viras L. G.: Atmospheric $\mathrm{PM}_{10}$ particle concentration measurements at central and peripherals urban sites in Athens and Thessaloniki, Greece, Global NEST Journal, 12(1), 71-83, 2010.

Kalivitis, N., Gerasopoulos, E., Vrekoussis, M., Kouvarakis, G., Kubilay, N., Hatzianastassiou, N., Vardavas, I., and Mihalopoulos, N.: Dust transport over the Eastern Mediterranean from TOMS, AERONET and surface measurements, J. Geophys. Res., 112, D03202, doi:10.1029/2006JD007510, 2007.

Kanakidou, M., Mihalopoulos, N., Kindap, T., Im, U., Vrekoussis, M., Dermitzaki, E., Gerasopoulos, E. , Unal, A., Koçak, M., Markakis, K., Melas, D., Youssef, A. F., and Moubasher, H.: Megacities as hot spots of air pollution in the East Mediterranean, doi:10.1016/j.atmosenv.2010.11.048, 2010.

Karnieli, A., Derimian, Y., Indoitu, R., Panov, N., Levy, R. C., Remer, L. A., Maenhaut, W., and Holben, B. N.: Temporal trend in anthropogenic sulfur aerosol transport from central and eastern Europe to Israel, J. Geophys. Res., 114, D00D19, doi:10.1029/2009JD011870, 2009.
Kaskaoutis, D. G., Kosmopoulos, P., Kambezidis, H. D., and Nastos, P. T.: Aerosol climatology and discrimination of different types over Athens, Greece, based on MODIS data, Atmos. Environ., 41, 7315-7329, doi:10.1016/j.atmosenv.2007.05.017, 2007.

Kosmopoulos, P. G., Kaskaoutis, D. G., Nastos, P. T., and Kambezidis, H. D.: Seasonal variation of columnar aerosol optical properties over Athens, Greece, based on MODIS data, Remote Sens. Environ., 112, 2354-2366, doi:10.1016/j.rse.2007.11.006, 2008.

Kaufman, Y. J., Herring, D. D., Ranson, K. J., and Collatz, G. J.: Earth Observing System AM1 mission to Earth, IEEE T. Geosci. Remote, 36(4), 1045-1055, 1998.

Koukouli, M. E., Kazadzis, S., Amiridis, V., Ichoku, C., Balis, D. S., and Bais, A. F.: Signs of a negative trend in the MODIS aerosol optical depth over the Southern Balkans, Atmos. Environ., 44 1219-1228, 2010.

Koulouri, E., Saarikoski, S., Theodosi, C., Markaki, Z., Gerasopoulos, E., Kouvarakis, G., Makela, T., Hillamo, R., and Mihalopoulos, N.: Chemical composition and sources of fine and coarse aerosol particles in the Eastern Mediterranean, Atmos. Environ., 42(26), 6542-6550, doi:10.1016/j.atmosenv.2008.04.0102008, 2008.

Kouvarakis, G., Doukelis, Y., Mihalopoulos, N., Rapsomanikis, S., Sciare, J., and Blumthaler, M.: Chemical, physical and optical characterisation of aerosols during PAUR II experiment, J. Geophys. Res., 107(18), 8141, doi:10.1029/2000JD000291, 2002.

Kubilay, N., Cokacar, T., and Oguz, T.: Optical properties of mineral dust outbreaks over the northeastern Mediterranean, J. Geophys. Res., 108(D21), 4666, doi:10.1029/2003JD003798, 2003.

Ladstätter-Weissenmayer, A., Kanakidou, M., Meyer-Arnek, J., Dermitzaki, E. V., Richter, A., Vrekoussis, M., Wittrock, F., and Burrows, J. P.: Pollution events over the East Mediterranean: Synergistic use of GOME, ground-based and sonde observations and models, Atmos. Environ., 41, 7262-7273 doi:10.1016/j.atmosenv.2007.05.031, 2007.

Lelieveld, J., Berresheim, H., Borrmann, S., Crutzen, P. J., Dentener, F. J., Fischer, H., Feichter, J., Flatau, P. J., Heland, J., Holzinger, R., Korrmann, R., Lawrence, M. G., Levin, Z., Markowicz, K. M., Mihalopoulos, N., Minikin, A., Ramanathan, V., de Reus, M., Roelofs, G. J., Scheeren, H. A., Sciare, J., Schlager, H., Schultz, M., Siegmund, P., Steil, B., Stephanou, E. G., Stier, P., Traub, M., Warneke, C., Williams, J., and Ziereis, H.: Global air pollution crossroads over the Mediterranean, Science 298, 794-799, 2002.

Liakakou, E., Bonsang, B., Williams, J., Kalivitis, N., Kanakidou, M., and Mihalopoulos, N.: C2-C8 NMHCs over the Eastern Mediterranean: Seasonal variation and impact on regional oxidation chemistry, Atmos. Environ., 43, 5611-5621, doi:10.1016/j.atmosenv.2009.07.067, 2009.

Masuoka, E., Fleig, A., Wolfe, R. W., and Patt, F.: Key characteristics of the MODIS data products, IEEE T. Geosci. Remote, 36(4), 1313-1323, doi:10.1109/36.701081, 1998.

Matthias, V., Balis, D., Bosenberg, J., Eixmann, R., Iarlori, M., Komguem, L., Mattis, I., Papayannis, A., Pappalardo, G., Perrone, M. R., and Wang, X.: Vertical aerosol distribution over Europe: Statistical analysis of Raman lidar data from $10 \mathrm{Eu}-$ ropean Aerosol Research Lidar Network (EARLINET) stations, 109, D18201, doi:10.1029/2004JD004638, 2004.

Melas, D., Kioutsioukis, I., and Lazaridis M.: The Impact of Sea 
Breeze on Air Quality in Athens Area, Advances in Air Pollution Modeling for Environmental Security, NATO Science Series, 54, 285-295, doi:10.1007/1-4020-3351-6_26, 2005.

Mitsakou, C., Kallos, G., Papantoniou, N., Spyrou, C., Solomos, S., Astitha, M., and Housiadas, C.: Saharan dust levels in Greece and received inhalation doses, Atmos. Chem. Phys., 8, 71817192, doi:10.5194/acp-8-7181-2008, 2008.

Papadimas, C. D., Hatzianastassiou, N., Mihalopoulos, N., Kanakidou, M., Katsoulis, B. D., and Vardavas, I.: Spatial and temporal variability in aerosol properties over the Mediterranean basin based on 6-year (2000-2006) MODIS data, J. Geophys. Res., 113, D11205, doi:10.1029/2007JD009189, 2008.

Papayannis, A., Balis, D., Amiridis, V., Chourdakis, G., Tsaknakis, G., Zerefos, C., Castanho, A. D. A., Nickovic, S., Kazadzis, S., and Grabowski, J.: Measurements of Saharan dust aerosols over the Eastern Mediterranean using elastic backscatter-Raman lidar, spectrophotometric and satellite observations in the frame of the EARLINET project, Atmos. Chem. Phys., 5, 2065-2079, doi:10.5194/acp-5-2065-2005, 2005.

Prasad, A. K., El-Askary, H., and Kafatos, M.: Implications of high altitude desert dust transport from Western Sahara to Nile Delta during biomass burning season, Environ. Pollut., doi:10.1016/j.envpol.2010.07.035, in press, 2010.

Querol, X., Alastuey, A., Pey, J., Cusack, M., Pérez, N., Mihalopoulos, N., Theodosi, C., Gerasopoulos, E., Kubilay, N., and Koçak, M.: Variability in regional background aerosols within the Mediterranean, Atmos. Chem. Phys., 9, 4575-4591, doi:10.5194/acp-9-4575-2009, 2009.

Remer, L. A., Kaufman, Y. J., Tanré, D., Mattoo, S., Chu, D. A., Martins, J. V., Li, R.-R., Ichoku, C., Levy, R. C., Kleidman, R. G., Eck, T. F., Vermote, E., and Holben, B. N.: The MODIS aerosol algorithm, products and validation, J. Atmos. Sci., 62, 947-973, doi:10.1175/JAS3385.1, 2005.

Remer, L. A., Tanré, D., and Kaufman, Y. J., Levy, R., and Mattoo, S.: Algorithm for remote sensing of tropospheric aerosols from MODIS, Collection 5, Product ID: MOD04/MYD04, http: //modis.gsfc.nasa.gov/data/atbd/atbd_mod02.pdf, 2006.
Remer, L. A., Kleidman, R. G., Levy, R. C., Kaufman, Y. J., Tanre, D., Mattoo, S., Martins, J. V., Ichoku C., Koren, I., Yu, H., and Brent N.: Holben Global aerosol climatology from the MODIS satellite sensors, J. Geophys. Res., 113, D14S07, doi:10.1029/2007JD009661, 2008.

Sciare, J., Oikonomou, K., Cachier, H., Mihalopoulos, N., Andreae, M. O., Maenhaut, W., and Sarda-Estève, R.: Aerosol mass closure and reconstruction of the light scattering coefficient over the Eastern Mediterranean Sea during the MINOS campaign, Atmos. Chem. Phys., 5, 2253-2265, doi:10.5194/acp-5-2253-2005, 2005.

Sciare, J., Oikonomou, K., Favez, O., Liakakou, E., Markaki, Z., Cachier, H., and Mihalopoulos, N.: Long-term measurements of carbonaceous aerosols in the Eastern Mediterranean: evidence of long-range transport of biomass burning, Atmos. Chem. Phys., 8, 5551-5563, doi:10.5194/acp-8-5551-2008, 2008.

Smirnov, A., Holben, B. N., Eck, T. F., Slutsker, I., Chatenet, B., and Pinker, R. T.: Diurnal variability of aerosol optical depth observed at AERONET (Aerosol Robotic Network) sites, Geophys. Res. Lett., 29, 2115, doi:10.1029/2002GL016305, 2002.

Washington, R., Todd, M.C., Engelstaedter, S., Mbainayel, S., and Mitchell, F.: Dust and the low-level circulation over the Bodele Depression, Chad: Observations from BoDEx 2005, J. Geophys. Res., 111, D03201, doi:10.1029/2005JD006502, 2006.

Zerefos, C. S. and Eleftheratos, K.: The Atmospheric Environment Division of the Center of Environmental Health \& Biophysics of the Biomedical Research Foundation of the Academy of Athens, in Bio Academy, A Quarterly Bulletin of the Biomedical Research Foundation, Academy of Athens, OctoberDecember 2007, Issue 1, 10-13, 2007.

Zerefos, C., Ganev, K., Kourtidis, K., Tzortziou, M., Vasaras, A., and Syrakov, E.: On the origin of $\mathrm{SO}_{2}$ above Northern Greece, Geophys. Res. Lett., 27(3), 365-368, 2000.

Ziomas, I. C.: The Mediterranean campaign of photochemical tracers-transport and chemical evolution (MEDCAPHOTTRACE): an outline, Atmos. Environ., 32(12), 2045-2-053, doi:10.1016/S1352-2310(97)00413-5, 1998. 